\title{
Team approach to ERCP-directed single-brush cytology for the diagnosis of malignancy
}

\author{
M. Urbano, A. Rosa, D. Gomes, E. Camacho, C. A. Calhau and M. Leitão \\ Department of Gastroenterology. University Hospital. Medicine School. University of Coimbra. Portugal
}

\section{RESUMEN}

Objetivo: evaluar la utilidad clínica de la citología con cepillo único durante la CPRE como método inicial de detección de los cánceres pancreaticobiliares, garantizando una relación muy cercana entre endoscopistas, citotécnicos y citopatólogos.

Diseño del estudio: los 125 citodiagnósticos considerados por este estudio corresponden al primer cepillado de cada paciente, realizado por uno de los tres miembros de un equipo fijo de endoscopistas en presencia del mismo citotécnico. Los frotis se fijaron inmediatamente con Merckofix ${ }^{\circledR}$ en aerosol, se tiñeron con Papanicolau y se analizaron por un mismo citopatólogo en un laboratorio exclusivamente dedicado a la citopatología digestiva y situado en la unidad de endoscopia.

Resultados: de los 125 diagnósticos citológicos, 94 se consideraron benignos, 4 sospechosos y 27 malignos. Estos hallazgos se compararon con el diagnóstico final de 45 lesiones malignas y 80 lesiones benignas, obtenido mediante patología quirúrgica o con un año al menos de seguimiento clínico. La comparación arrojó 30 positivos verdaderos, 78 negativos verdaderos, 1 positivo falso y 16 negativos falsos, lo que corresponde a una sensibilidad, una especificidad, un valor pronóstico positivo, un valor pronóstico negativo y una precisión del 65,2, el 98,7, el 96,8, el 83 y el 86,4\%, respectivamente.

Conclusión: los resultados parecen confirmar la utilidad de un abordaje en equipo eficaz de la citología con cepillo guiada por CPRE para el diagnóstico del cáncer pancreaticobiliar. Sin embargo, la sensibilidad sigue siendo más bien baja.

Palabras clave: Cáncer de páncreas. Cáncer biliar. Colangiopancreatografía retrógrada endoscópica (CPRE). Citología en cepillo. Diagnóstico.

\begin{abstract}
Objective: to evaluate the clinical usefulness of single-brush cytology performed at ERCP as initial method for detecting pancreatobiliary malignancy, ensuring a very close relationship between endoscopists, cytotechnicians, and cytopathologists.

Study design: all 125 cytodiagnoses considered in this study correspond to the first brushing for each patient, collected by one of the three members of a fixed team of endoscopists in the presence of the same cytotechnician. Smears were fixed immediately with Merckofix ${ }^{\circledR}$ spray, stained with Papanicolau, and analyzed by the same cytopathologist in a laboratory exclusively devoted to gastrointestinal cytopathology located at the endoscopy unit.

Results: of 125 cytological diagnoses 94 were considered benign, 4 suspicious, and 27 malignant. These findings were compared to the final diagnosis of 45 malignant and 80 benign lesions obtained either by surgical pathology or after at least one year of clinical follow-up. The comparison yielded 30 true positives, 78 true negatives, 1 false positive and 16 false negative results, which corresponds to a sensitivity, specificity, positive predictive value, negative predictive value, and accuracy of 65.2 , 98.7, 96.8, 83, and $86.4 \%$, respectively.

Conclusion: results seem to confirm the usefulness of an effective team approach to ERCP-directed brush cytology for the diagnosis of pancreatobiliary malignancy. However, sensitivity continues to be rather low.
\end{abstract}

Key words: Pancreatic malignancy. Biliary malignancy. Endoscopic retrograde cholangiopancreatography (ERCP). Brush cytology. Diagnosis.

Urbano M, Rosa A, Gomes D, Camacho E, Calhau CA, Leitão M. Team approach to ERCP-directed single-brush cytology for the diagnosis of malignancy. Rev Esp Enferm Dig 2008; 100: 462-465.

Recibido: 23-01-08

Aceptado: 29-04-08.

Correspondencia: Marta María Venturini Carreira Urbano. Departamento de Gastroenterología. Hospitais da Universidade de Coimbra. Praceta Mota Pinto.3000-075 Coimbra, Portugal. e-mail: martaurbano@huc-saude.pt

\section{INTRODUCTION}

Brush cytology is the most commonly used method when pathologic confirmation of pancreaticobiliary malignancy is required during endoscopic retrograde cholangiopancreatography (ERCP) (1-6). Intraductal 
biopsy, the only technique that can provide a true tissue sample, requires technical finesse and usually a large sphincterotomy for access, which precludes its routine application (7). In comparison, the ERCP-directed brush sampling can be performed without technical difficulties, almost without complications (2), and is relatively inexpensive.

However, although highly specific, ERCP-directed brush cytology is not very sensitive, due to a high rate of false-negative diagnoses $(3,4,8-18)$. Several ways have been proposed to overcome this limitation, such as: the use of a different procedure to prepare the brush samples (8); making more malignant cells available for cytopathologic evaluation by increasing the brushing cellular yielding $(2,4,19,20)$; combining brush cytology with some others techniques $(2,6,7,21-26)$. While the first two approaches are mostly ineffective, multimodal sampling can improve the sensitivity, although the simplicity that characterizes the ERCP-directed brush cytology is somehow lost.

Our Department of Gastroenterology benefits from having a dedicated laboratory of cytopathology situated at the Endoscoy Unit, which allows for a very close relationship between endoscopists, cytotechnician and cytopathologist, with well defined routine procedures.

The aim of this study was to find out if the sensitivity of ERCP single brushing cytology, as the quickest and least expensive first pathological diagnostic of pancreaticobiliary malignancy, can be improved by a team approach to the acquisition and interpretation of the material. The effectiveness of a team approach has been reported in other areas of brush cytology but not, as far as we know, in ERCP-direct brush cytology.

\section{MATERIALS AND METHODS}

\section{Patient population}

One-hundred fifty one consecutive patients with suspected lesions of the pancreaticobiliary system, including the ampulla of Vater, were submitted to ERCP-directed brush cytology, between January 2000 and June 2006. A single-brush specimen was collected from each patient. When a patient was submitted to more than one ERCP examination, only the cytological diagnosis of the first brushing specimen was considered in this assessment.

Our evaluation refers to 125 patients, since 23 patients had not adequate clinical or pathological follow up, and in 3 (1.9\%) cases the brushing smears had no cellularity.

Of the 125 studied patients with complete assessment, 61 were female, with ages ranged from 31 to $89 \mathrm{yr}$ (mean $69 \mathrm{yr}$ ), and 64 were males with ages from 36 to $87 \mathrm{yr}$ (mean $68.8 \mathrm{yr}$ ).

\section{Sample collection and preparation for routine cytology}

For each patient, two or three smears were prepared from the brushing specimen, depending on the evaluation of the amount of collected material by the cytotechnician, who was always present at the endoscopy room. The smears were immediately fixed with Merckofix ${ }^{\circledR}$ spray and stained with Papanicolau.

\section{Cytological interpretation of smears}

The cytological diagnosis reflects the cytopathologist experience in properly weighting the relative importance of the more relevant cytomorphologic features, since not all of them are present in all cases at the same time. The following main criteria for malignancy were considered:

- Increased nuclear/cytoplasm ratio.

- Chromatin clumping.

- Nuclear polymorphism in size and shape.

- Prominent nucleoli.

- Vacuolated or basophilic cytoplasm.

-Overlapping nuclei.

- Nuclear moulding.

- Nuclear membrane irregularity.

- Multiple nucleoli.

- Nuclear polarity.

-Nucleos em palissada.

- Necrosis.

In our experience, in most cases, cholangiocarcinoma shows morphological features of a non-specific adenocarcinoma, as it is illustrated in figure 1 . Nevertheless we found out that there are major features suggestive of cholangiocarcinoma, namely: nuclear moulding, chromatin clumping, nuclear membrane irregularity, increased nuclear/cytoplasm ratio. One should notice that two of these features are considered as minor ones by other authors (27) in their reclassification of "atypical" diagnoses.

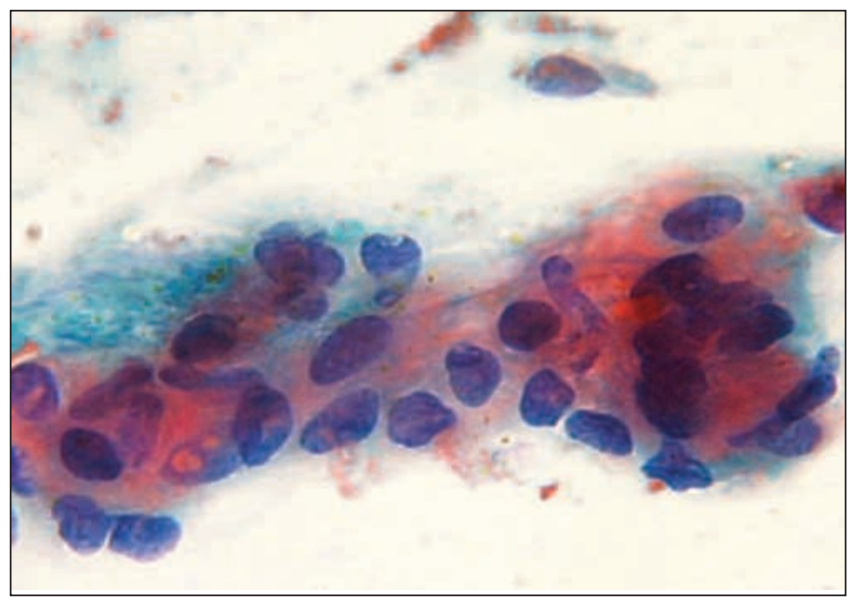

Fig. 1. True positive-cholangiocarcinoma showing morphological features of a non-specific adenocarcinoma (Papanicolaou stain, x 400). 
As far as pancreatic carcinoma is concerned, the major features are nuclear polarity, prominent nucleoli, chromatin clumping and tridimensional groups with overlapping nuclei.

\section{RESULTS}

Of the 125 cytological diagnoses, 94 were recorded as benign, 4 as suspicious for malignancy and 27 as malignant. These findings were compared with the final diagnosis established either by surgical pathology or by at least one year of clinical follow up. In the final diagnosis, 46 were malignant (13 pancreatic carcinomas, 12 cholangiocarcinomas, 15 ampullary carcinomas, 5 gallbladder carcinomas, one invasive colon carcinoma) and 79 were benign. In the analysis of ERCP cytology accuracy, positive for carcinoma and suspicious brushings were combined in a single category (6). Thus, 3 of the 4 cases that were reported as suspicious and turned out to be malignant were considered as true positives; the other one, which turned out to be benign, was considered as a false positive.

Comparing the cytological diagnosis with the final one, we found 30 true positives, 78 true negatives, 1 false positive and 16 false negative (Table I). Examples of a true positive and a false negative are shown in figures 1 and 2 respectively.

Table I. Results of 125 routine ERCP brush cytology diagnosis

\begin{tabular}{lcccc}
\hline & True positive & True negative & False positive & False negative \\
\hline Number & 30 & 78 & 1 & 16 \\
Percentage & $24 \%$ & $62.4 \%$ & $0.8 \%$ & $12.8 \%$ \\
\hline
\end{tabular}

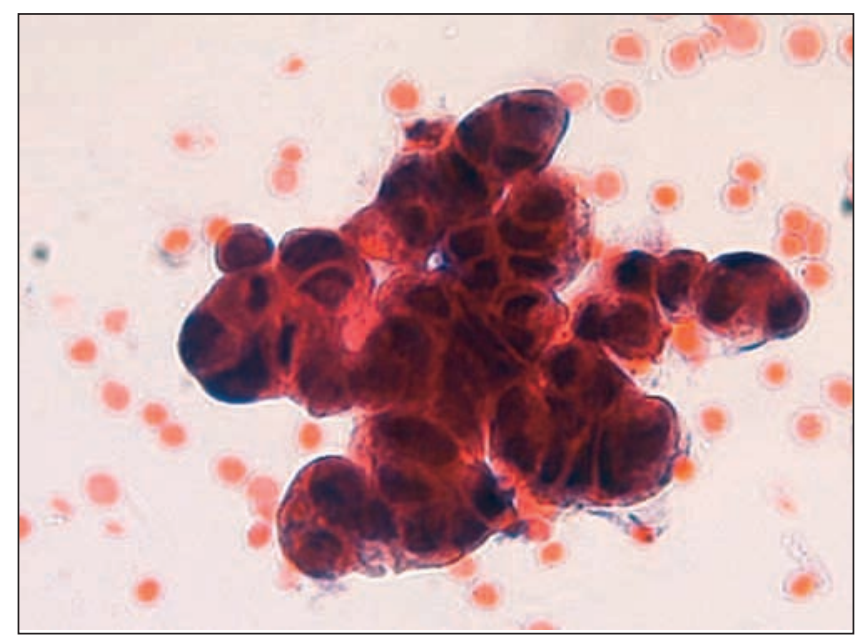

Fig. 2. False negative. Crowded group, moulding, increased N/C ratio and coarse chromatin were not considered relevant as malignant features (Papanicolau stain, $x$ 400).
The sensibility, specificity, positive predictive value (PPV), negative predictive value (PNV) and accuracy of the method are shown in table II.

In a more detailed analysis the cytology confirmed 7 out of 13 pancreatic carcinomas, 8 of the 12 cholangiocarcinomas, 13 of 15 ampulomas, 2 of the 5 gallbladder carcinoma, but failed to recognize as malignant one invasive tumour.

Table II. Performance of the routine ERCP brush cytology

\begin{tabular}{lcccc}
\hline Sensitivity & Specificity & PPV & NPV & Accuracy \\
\hline $65.2 \%$ & $98.7 \%$ & $96.8 \%$ & $83 \%$ & $86.4 \%$ \\
\hline
\end{tabular}

\section{DISCUSSION}

The examination of cytological specimens obtained by brushing at ERCP has become an established initial diagnostic method for pancreaticobiliary malignancy. However, notwithstanding its very high specificity (usually greater than $95 \%$ ), its reported sensibility is generally low (7), ranging from 18 to $60 \%$ according to a recent review of 10 published selected series (4,9-18).

We have correlated the cytological evaluations of brush samples obtained from 151 consecutive patients with surgery or clinical outcomes. The assessment refers to 125 of the 151 examined patients, since 23 patients had not adequate clinical or pathological follow up and in 3 cases the brush samples contained no cellular material. These results are in line with other reported series (17). Moreover, the 3 samples without cellularity corresponded to benign lesions, which is a further justification for its exclusion from the assessment.

Our results for specificity and predictive positive value compare well with the ones referred in the selected series (4,9-18), but the results for sensibility, predictive negative value and accuracy were higher. This seems to show that having a coherent group, performing well trained routines for the acquisition, preparation and analysis of the cytological material, can improve the sensitivity of the method.

However, one should notice that not all results are directly comparable, since some of them refer only to a specific pathology. Moreover, as J. G. Lee (7) rightly pointed out, the ERCP-directed brush cytology can be assessed differently from either the clinical or the brushing-technique point of view. Indeed, the cytopathologist only evaluates the specimens that are submitted to cytomorphological examination, ignoring in most cases the patients with failed access, failed brushings or lost specimens.

In our practice, it is impossible to loose specimens, since the laboratory for cytopathology is situated at the endoscopy unit. On the other hand, the 3 cases without 
cellularity (failed brushings) turned out to correspond to benign lesions and were excluded because they could not be considered as false negatives nor as false positives. Finally, as far as the failed access is concerned, we have classified as false negatives 11 cases whose specimens were not representative of the lesion, which means that the brush didn't reach the malignant site. This seems to be an unavoidable limitation of the brushing technique performed during ERCP, although we think that it could be minimized using a guided-wire brush in a regular way.

The sensitivity of $65.2 \%$ was due to the 16 false-negative cytological reports. These resulted from 11 cases where the cellular material was not representative of the lesion and 5 which were wrongly classified as reactive /inflammatory processes. Indeed, we didn't consider as relevant the presence of some features like nuclei moulding, coarse chromatin, increased nuclear/cytoplasm ratio and membrane irregularity, in the complete absence of other features that like enlarged nucleoli and nuclear polymorphism (Fig. 2).

The single false-positive of this study was reported as suspicious due to the presence of a group of cells with increased nuclear/cytoplasm ratio and overlapping nuclei, in a sample with poor celullarity.

In conclusion, the ERCP-brush cytology is a simple, relatively inexpensive and useful initial method for detecting pancreaticobiliary malignancy, but its sensitivity is still rather low due to false-negative diagnosis. However, if the brushing would be done sliding the brushing device over a previously insert guide wire, results could be improved.

In our experience, a group of endoscopists with well established practices, working in close connection with a dedicated laboratory of cytopathology, can achieve sensitivities of $65.2 \%$, for the diagnosis of pancreaticobiliary malignancy, at ERCP.

\section{REFERENCES}

1. Osnes M, Serck-Hansenn A, Myren J. Endoscopic retrograde brush cytology (ERBC) of the biliary and pancreatic ducts. Scand J Gastroenterol 1975: 10: 829-31.

2. de Bellis M, Sherman S, Fogel EL, et al. Tissue sampling at ERCP in suspected malignant biliary strictures (Part 2). Gastrointest Endosc 2002: 56: 720-30.

3. Logrono R, Kurtycz DF, Molina CP, et al. Analysis of false-negative diagnoses on endoscopic brush cytology of biliary and pancreatic duct strictures: experience at 2 university hospitals. Arch Pathol Lab Med 2000: 124 (3): 387-92.

4. Fogel EL, deBellis M, McHenry L, et al. Effectiveness of a new long cytology brush in the evaluation of malignant biliary obstruction: a prospective study. Gastrointest Endosc 2006; 63: 71-7.

5. Gress TM. Molecular diagnosis of pancreatobiliary malignancies in brush cytologies of biliar strictures. Gut 2004: 53: 1727-9.
6. Furmanczyk PS, Grieco VS, Agof SN. Biliary brush cytology and the detection of cholangiocarcinoma in primary sclerosing cholangitis. Am J Clin Pathol 2005: 124: 355-60.

7. Lee JG. Brush cytology and the diagnosis of pancreatobiliary malignancy during ERCP. Gastrointest Endosc 2006: 63: 78-80.

8. Duggan MA, Brasher P, Medlicott SA. ERCP-directed brush cytology prepared by the Thinprep ${ }^{\circledast}$ method: test performance and morphology of 149 cases. Cytopathology 2004: 15: 80-6.

9. Foutch PG, Kerr DM, Kummet TD. A prospective controlled analysis of endoscopic cytotechniques for diagnosis of malignant biliary structures. Am J Gastroenterol 1991: 86: 577-80.

10. Lee JG, Leung JW, Baillie J, et al. Benign, dysplastic, or malignan -making sense of endoscopic bile duct brush cytology: results in 149 consecutive patients. Am J Gastroenterol 1995: 90: 722-6.

11. Ponchon T, Gagnon P, Berger F, et al. Value of endobiliary brush cytology and biopsies for the diagnosis of malignant bile duct stenosis: results of a prospective study. Gastrointest Endosc 1995: 42: 565-72.

12. Pugliese V, Conio M, Nicolo G, et al. Endoscopic retrograde forceps biopsy and brush cytology of biliary strictures: a prospective study. Gastrointest Endosc 1995: 42: 520-6.

13. Glasbrenner B, Ardan M, Boeck W, et al. Prospective evaluation of brush cytology of biliary strictures during endoscopic retrograde cholangiopancreatography. Endoscopy 1999: 31: 712-7.

14. Mansfield JC, Griffin SM, Wadehra V, et al. A prospective evaluation of cytology from biliary strictures. Gut 199: 40: 671-7.

15. Jailwala J, Fogel EL, Sherman S. Triple tissue sampling at ERCP in malignant biliary obstruction. Gastrointest Endosc 2000: 51: 38390.

16. Macken E, Drijkoningen M, Van Aken E, et al. Brush cytology of ductal strictures during ERCP. Acta Gastroenterol Belg 2000: 63: 254-9.

17. Stewart CJR, Mills PR, Carter R, et al. Brush cytology in the assessment of pancreatico-biliary strictures: a review of 406 cases. J Clin Pathol 2001: 54: 449-55.

18. Harewood GC, Baron TH, Stadheim LM, et al. Prospective, blinded assessment of factors influencing the accuracy of biliary cytology interpretation. Am J Gastroenterol 2004: 99: 1464-9.

19. De Bellis M, Fogel EL, Sherman S, et al. Influence of stricture dilation and repeat brushing on the cancer detection rate of brush cytology in the evaluation of malignant biliary obstruction. Gastrointest Endosc 2003: 58: 176-82.

20. Ornellas LC, Santos GC, Nakao FS, et al. Comparison between endoscopic brush cytology performs before and after biliary stricture dilatation for cancer detection. Arq Gastroenterol 2006: 43: 20-3.

21. Van Laethem JL, Bourgeois V, Parma J, et al. Relative contribution of Ki-ras gene analysis and brush cytology during ERCP for the diagnosis of biliary and pancreatic diseases. Gastointest Endosc 1998: 47: 479-85.

22. Krishnamurthy S, Katz RL, Shumate A, et al. DNA image analysis combined with routine cytology improves sensitivity of common bile duct brushing. Cancer (Cancer Cytopathology) 2001: 93: 229-33.

23. Siqueira E, Schoen RE, Silvermann W, et al. Detecting cholangiocarcinoma in patients with primary sclerosing cholangitis. Gastrointest Endosc 2002: 56: 40-7.

24. Kipp BR, Stadheim LM, Halling SA, et al. A comparison of routine cytology and fluorescence in situ hybridization for the detection of malignant bile duct strictures. Am J Gastroenterol 2004: 99: 1675-81.

25. Baron TH, Harewood GC, Rumalla A, et al. A prospective comparison of digital image analyses and routine cytology for the identification of malignancy in biliary tract strictures. Clin Gastroenterol Hepatol 2004: 2 (3): 214-9.

26. Khalid A, Pal R, Sasatomi E, et al. Use of microsatellite marker loss of heterozygosity in accurate diagnoses of pancreaticobiliary malignancy from brush cytology samples. Gut 2004: 53: 1727-9.

27. Okonkwo AM, de Frias DV, Gunn R, et al. Reclassification of "atypical" diagnoses in endoscopic retrograde cholangiopancreaticography - guided biliary brushings. Acta Cytol 2003; 47 (3): 435-42. 